Vol.61, no.spe: e18000520, 2018

http://dx.doi.org/10.1590/1678-4324-smart-2018000520 ISSN 1678-4324 Online Edition
BRAZILIAN ARCHIVES OF BIOLOGY AND TECHNOLOGY

AN INTERNATIONAL JOURNAL

\title{
Protection of Grid Connected Photovoltaic Systems (GCPVS)
}

\author{
Jardel Eugenio da Silva ${ }^{{ }^{*}}$, Danilo Carvalho de Gouveia ${ }^{\mathbf{1}}$, Jair Urbanetz Junior ${ }^{1,2}$ \\ ${ }^{1}$ Programa de Pós-Graduação em Sistemas de Energia, Universidade Tecnológica Federal do Paraná, Curitiba, \\ Brasil; ${ }^{2}$ Programa de Pós-Graduação em Engenharia Civil, Universidade Tecnológica Federal do Paraná, Curitiba, \\ Brasil.
}

\begin{abstract}
Installations of photovoltaic systems connected or not to the electrical network have become increasingly popular, but it is often carried out by unqualified people using low quality components. The present study aims to describe the methodology adopted for the protection of grid connected photovoltaic systems (GCPVS) and the implications caused by their lack. Photovoltaic modules are typically installed in galvanized, painted, stainless aluminum or steel structures, which must be connected to a common ground, as these structures and any other components of the system could be energized by the photovoltaic array and may cause serious injuries or even death during routine maintenance, these fatalities can still result in ramifications for the entire industry, with millions of dollars in liability (for death or injury), negative publicity for GCPVS, and increased complications in obtaining licenses. Also, its components must be of good quality and the systems of protection must be well dimensioned and correctly installed, in order to avoid fire and electric damages, with reduction of possible damages in cases of short circuits.
\end{abstract}

Keywords: Photovoltaic systems, Grounding, Photovoltaic modules, Protection.

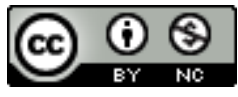

*Author for correspondence: jardel.eugenio@ hotmail.com 


\section{INTRODUCTION}

The installations of photovoltaic systems connected or not to the electrical network have become increasingly popular, but it is often carried out by unqualified people using low quality components. The present study aims to describe the methodology adopted for the protection of photovoltaic systems connected to the grid (GCPVS) and the implications caused by its lack. Photovoltaic modules are typically installed in galvanized, painted, stainless steel or aluminum structures, which must be connected to a common ground, since these structures and any other components of the system, which could be energized by the photovoltaic matrix, can cause serious injuries or even death during routine maintenance, these fatalities can still result in ramifications for the entire industry, with millions of dollars in compensation (for death or injury), negative publicity for GCPVS, and increased complications in obtaining licenses.

Also its components must be of good quality and the systems of protection must be well dimensioned and correctly installed, in order to avoid fire and electrical damages, with reduction of possible damages in cases of short circuits. Therefore, the objective of this study is to address the main technologies used to protect SFVCR, based on the methods adopted in the United States, since in Brazil there are no current norms or regulations that address this issue ${ }^{1}$.

\section{GRID-CONNECTED PHOTOVOLTAIC SYSTEMS (GCPVS)}

A GCPVS consists basically of the photovoltaic panel, which converts the energy of the sun into electrical energy in direct current by an inverter, which converts the direct current to alternating current and, in addition to making it available for installation, also injects the surplus of that energy in the power distribution company's network by the bidirectional meter, which accounts for the energy injected into the distributor's grid. ${ }^{2}{ }^{3}$ Figure 1 shows these components.
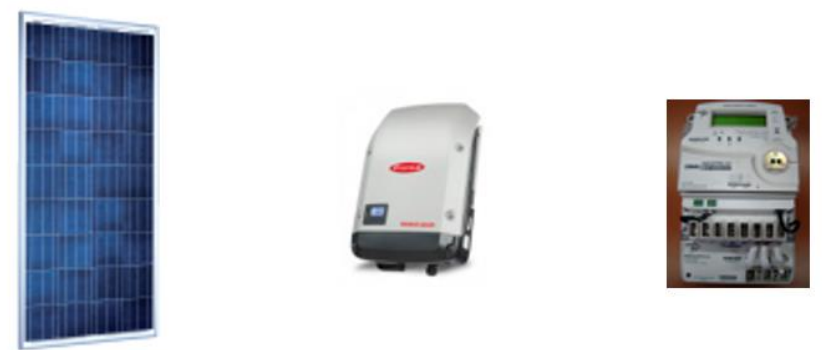

Figure 1- Photovoltaic panel, inverter and bidirectional meter Source: Adapted. ${ }^{4}$

In a photovoltaic system connected to the electricity grid (GCPVS), besides the protection system, the quality of the inverters must be analyzed, since the inverter must be disconnected from the grid in the event of a lack of electricity by the power distribution company, as well as having a sinusoidal wave of good quality, so as to avoid possible disturbances in the systems of protection of the distribution company. 


\section{Grounding of GCPVS}

A photovoltaic system is considered grounded when one of the conductors of the DC circuit, positive or negative, is connected to the grounding system, which in turn is connected to ground. ${ }^{7} 5$

Photovoltaic modules are typically installed in galvanized, painted or stainless steel or aluminum structures. These structures and any other components, which could be energized by the photovoltaic matrix and which may be accessible during routine maintenance, should be connected to a common ground as shown in Table. 2.

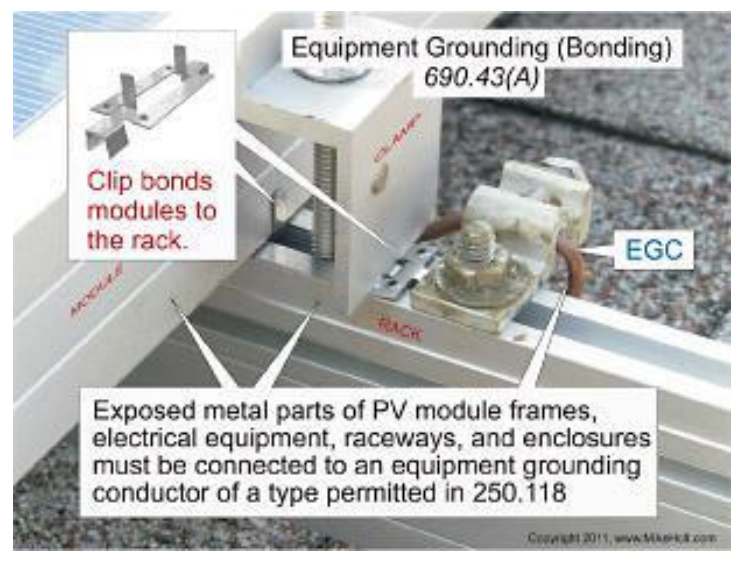

Figure 2- Grounding of a photovoltaic system Source: Adapted. ${ }^{7}$

The National Electric Code (NEC) does not provide guidance on how metal parts should be joined together to provide reliable grounding and it is beyond the scope of the Underwriters Laboratories (UL) 1703 standard for flat plate PV modules and panels. There have not been any industry guides on how to design, install, or maintain a reliable external electrical connection between metal parts for more than 20 years, leaving the installer with no option but to improvise solutions to this problem, resulting in a surprisingly large number of field systems that violate UL standards by failing to comply with the method prescribed by the module's grounding installation manual, often leaving the module structures ungrounded, or creating an electrical connection, with improvised methods, without testing, field validation, or certification to verify that the newly created connection would last the system's lifespan. Such practices pose a safety risk to maintenance staff, leading to serious injury or death, and such event would also have ramifications for the entire industry, with millions of dollars in compensation (for death or injury), negative publicity for the photovoltaic system connected to the electricity grid (GCPVS), and increased complications in obtaining licenses. ${ }^{5}$ 


\section{Standard UL-1741}

In an GCPVS system, one of the conductors of the DC circuit, positive or negative, must be connected to the grounding system, which in turn must be connected to ground. These grounding requirements require that each inverter has at least three terminals available and that they are connected together with the inverter housing, all on an appropriate bus in the inverter itself. ${ }^{5}$

grounding in a PV arrangement is usually done through the Ground Fault Protection Device (GFPD) inside the inverters connected to the network, so that this device plays the role of the system connection jumper. The presence of this connection jumper requires, in accordance with UL Standard 1741, that inverters have clearly marked terminals marked for the conductor connection of the grounding electrode, as shown below in Fig. 3.

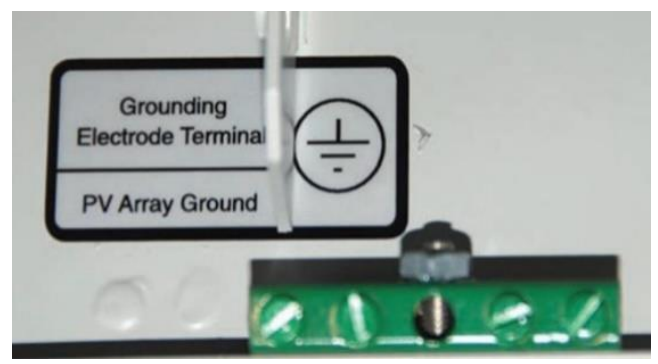

Figure 3 - Earthing electrode conductor terminal Source: Adapted ${ }^{7}$.

The UL 1741 also requires that the input DC and the output on the inverters have terminals, wiring, or other arrangements for accepting equipment grounding conductors (EGC). These grounding requirements require that each inverter has at least three terminals available and that they are electrically connected to each other and to the inverter housing, all on an appropriate bus in the inverter itself, as shown in Fig. 4.

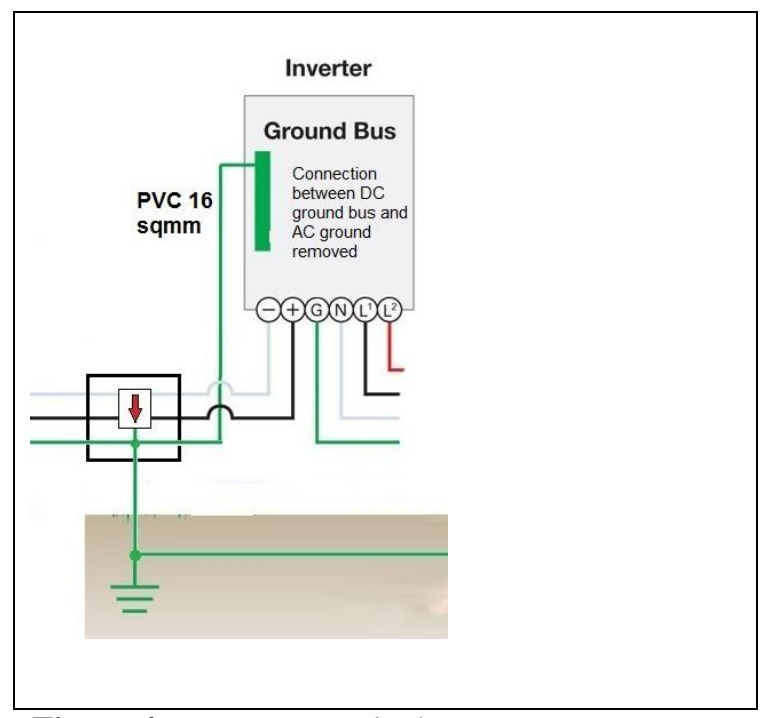

Figure 4 - Inverter terminals Source: Adapted. ${ }^{6}$ 
Other countries with standards and grounding standards different from the US, accept inverters without a grounding electrode terminal.

\section{Protection Devices}

The protective devices are available to be added to the isolated photovoltaic systems as well as connected to the mains. Some inverters already come equipped with these protection devices, which serve as junction and in the presence of fault current, they can open this junction. If these devices do not perform their junction function, they simply act by disconnecting the current (negative and positive) conductors from the circuit ${ }^{7}$.

Incorrect or faulty installed device such as AC isolator switches being used erroneously in DC circuits, may result in a buildup of heat inside the switch compartment leading to fire as shown in Fig. 5.

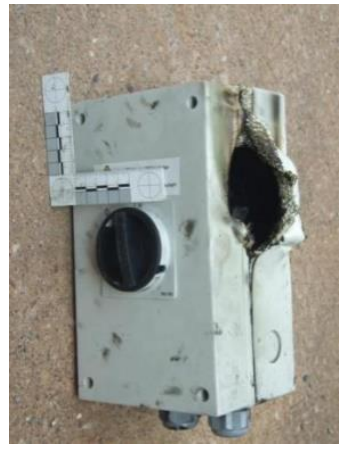

Figure 5 - Switch compartment Source: Adapted. ${ }^{7}$

Other incidents resulted from the use of defective inverters or absence of DC switches, and any switching faults or connection on the DC side of a system can result in the generation of a high temperature arc that can start fire, as shown in Fig. 6. DC arcs can be difficult to extinguish and pose a risk to firefighters. ${ }^{8}$

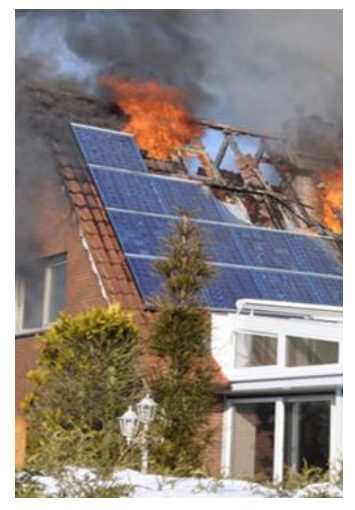

Figure 6 - Fire involving photovoltaic panels Source: Adapted. ${ }^{7}$ 


\section{CONCLUSION}

Photovoltaic systems are exposed to the effects of lightning and are short-circuited, resulting in high currents and consequently, increase the risk of fire and damage to electrical appliances. In order to reduce these risks, protective devices are installed in these systems, which are capable of detecting excessive short-circuit current or a lack of grounding, and are capable of interrupting it. The over current protection components, located on the DC conductor, constitute a current sensor that measures the current difference between the positive and negative conductors. In any photovoltaic arrangement, leakage currents are expected and they increase with the aging of systems, especially in rainy environments. In order for the system not to get unprotected unnecessarily, the over current limit of these devices, which varies according to the size of the system, should allow leakage currents up to certain values. NEC requires that protective devices be capable of identifying and disrupting ground fault currents, however, it says nothing about the necessary procedures to achieve them.

Compared to Brazil, the solar energy industry in the United States has been used longer and, consequently, has increasingly improved standards. It can be concluded that for photovoltaic systems to work correctly and without risk of accidents or fire, it is necessary that in Brazil there is a regulation not only for the components of the system, but also for the professionals who will install and maintain the GCPVS.

\section{REFERENCES}

1- Assaife BM. Aterramento e Proteção de Sistemas Fotovoltaicos, 2013. Tese de

Doutorado. Universidade Federal do Rio de Janeiro. [Internet]. [acesso em 2017 ag 10]. Available in: http://monografias.poli.ufrj.br/monografias/monopoli10006458.pdf

2- Urbanetz JJ. Sistemas Fotovoltaicos Conectados a Redes de Distribuição Urbanas: Sua influência na qualidade da energia elétrica e análise dos parâmetros que possam afetar a conectividade, 2010: 189. Tese de Doutorado. UFSC: Florianópolis - SC, 2010.

3- Ministério de Minas e Energia. Análise da Inserção da Geração Solar na Matriz Elétrica Brasileira. Rio de Janeiro: Empresa de Pesquisas Energéticas, 2012.

4- Gerasol. Sistemas Conectados à rede, 2016. [acesso em 2017 ago 14]. Available in: http://www.gerasolbr.com.br/energia-solar.html

5- Wiles JC. Photovoltaic System Grounding: College of Engineering: New Mexico State

University. Outubro, 2012. [Internet]. [acesso 2017jun 19]. Available in: http://www.solarabcs.org

6- Step-By-Step Guide to Going Solar. [acesso em 2017 jun 19]. Available in:

http://www.thesolarplanner.com/steps_page8.html

7- International Fire Professional, 2013 Oct; Issue 6. [acesso em 2017 maio 20]. Available in:

https://www.thenbs.com/knowledge/fire-safety-and-solar-electric-and-photovoltaic-systems

Received: December 21, 2017;

Accepted: August 01, 2018

Braz. Arch. Biol. Technol. v.61, no.spe: e18000520 2018 